\title{
IRISH FILM AND MEDIA STUDIES PUBLICATIONS
}

\author{
The Year in Review- 2014 \\ Ruth Barton (ed.)
}

Copyright (c) 2015 by the authors. This text may be archived and redistributed both in electronic form and in hard copy, provided that the authors and journal are properly cited and no fee is charged for access.

\section{Introduction}

Ruth Barton

Rex Ingram: Visionary Director of the Silent Screen (2014)

by Ruth Barton

Brian McIlroy

The Black Irish Onscreen: Representing Black and Mixed Race Identities

on Irish Film and Television (2013)

by Zélie Asava

Maria Pramaggiore

Masculinity and Irish Popular Culture (2014)

by Tony Tracy and Conn Holohan (eds.)

Emma Radley 179

“Other People's Diasporas": Negotiating Race in Contemporary Irish and Irish American Culture(2013)

by Sinéad Moynihan

Kathleen Vejvoda

The Woman Who Married Clark Gable (2013) / Thaddeus O'Sullivan:

The Early Films, 1974-1985. 2 DVD set (2014)

by Lance Pettitt and Beatriz Kopschitz Bastos (eds.)

Jerry White 
Irish Film and Media Studies Publication. Introduction

Ruth Barton

Welcome to the new "Irish Film and Media Studies Publications" section of Estudios Irlandeses! This section has been inaugurated as a response to the proliferation of new publications in this area. As you will see, certain of the books are dedicated specifically to the discussion of Film and Media, while others have been included by virtue of a substantial interest in those topics.

This interdisciplinarity is a reflection of Film and Media's increasing absorption into third level teaching and student learning. In my university, for example, we are collaborating with subjects as far removed from our own as Physics and Medicine to teach their students the basics of communicating with each other and the public through making and showing films. Film and Media are well established in Departments of English and Language Departments worldwide and in specific "Studies" departments, in our case within Irish Studies. Historians are moving beyond berating films for "getting it wrong" towards a more nuanced approach that rightly sees films as repositories of socio-cultural values.

Irish cinema has tended to be read this way too as reflecting and reflecting on national and social concerns. Irish Media Studies is newer but often studied for the same reasons. However, as several of the reviews in this section reflect, a vocal cohort of newer scholars is agitating for a more theoretically informed approach to both disciplines and this, in turn, should attract a wider interest group to their study. As Irish Film and Media studies develop, then we can look forward to an even greater diversity of writings in the area, from the historical, to the social, to the theoretical. Lucky the Reader when all these come together.

A word of warning is rightly sounded by Gerry White, whose review is a reminder of just how hard it is to view many of the key productions discussed in these various publications. This is indeed a concern and one hopes that more will be done in the future to ensure that global audiences and students can access Irish Film and Media products as easily as they can Hollywood and American film, TV, Old and New Media.

Finally, this section is intended to complement the excellent work of Roddy Flynn and Tony Tracy in compiling and editing the annual Estudios Irlandeses review of Irish Film and TV. I look forward already to a new round of publications for 2016, to new voices, and to new critical and historical writings on Irish Film and Media.

Ruth Barton is lecturer in Film Studies at Trinity College Dublin and the author of a number of books on Irish cinema. Her most recent monograph is Rex Ingram: Visionary Director of the Silent Screen (University Press of Kentucky, 2014). 


\section{Rex Ingram: Visionary Director of the Silent Screen}

By Ruth Barton

Lexington, Kentucky: The University Press of Kentucky, 2014.

ISBN 978-0-8131-4709-3 (Ebook also available)

Hardback, 320pp. 74 b/w photos

\section{Reviewer: Brian McIlroy}

Picking through the paper and visual trail of anyone's life is fraught with pitfalls and necessitates calculated guesswork and an informed sense of historical time and place. In her new critical biography of Rex Ingram, Ruth Barton proves to be a prudent guide to the past and makes an excellent case that we should as film historians have a closer look at this filmmaker's overall achievements. Barton's task in establishing plausible scenarios from the voluminous mythmaking surrounding this Irishborn director has been a challenging one, but she succeeds in completing it and in convincing the reader that Ingram was a complex figure who cannot be easily categorized. He is best known today as the director of The Four Horsemen of the Apocalypse (1921) starring Rudolph Valentino, a film regularly listed among the top fifty silent era productions ever made, and while Barton gives this film its due, she invites us to unfurl a larger canvas to appreciate Ingram's overall aesthetic. While some of his films remain lost or reside in poor condition with limited access, the bulk of his major work can be viewed with some effort, and future digital developments along with this bio-critical text may excite new scholarly interest.

Rex Ingram Montgomery Hitchcock (18931950) was born in Dublin into a family whose patriarch would become a Church of Ireland rector in County Tipperary. A middle-class Protestant in southern Ireland meant he led a relatively privileged life, exploring freely castles and grand old Irish houses and mansions. His first experience of cinema, if his unpublished memoir is to be believed, was part of Cleary's touring circus. Sent off to boarding school before even a teenager, he was to suffer, at the tender age of fifteen, the death of his sickly mother. Barton naturally gives some thought to this sad event and its impact on the sensitive Rex. It is possible that this short-circuiting of his relationship with his mother led, as the biographer suggests, to his too quickly seeing women as either pure-hearted souls or tempting sirens. Certainly, his female characters tend to be one-dimensional, as if he sculpted them in time as essentially static. In 1915, he took his mother's name, Ingram, as his surname. One wonders what his father felt about that, even if they appeared to have a respectful close relationship down the years despite their later religious differences.

As Woody Allen has famously said, most success is simply due to turning up on time and enduring hard work, but timing is also key. This fact appears to be very true of Rex Ingram - he was late joining up for the First World War (though he may have nearly been shipped to France as a barely competent pilot), too old for the Second World War, and out of the country for all the heady Irish matters between 1916 and 1922. Yet, his timing was impeccable to advance a film career in the United States. After failing to get into Trinity College Dublin, much to his father's shame, he left Ireland for the USA in 1911, and after a period studying sculpture with Lee Lawrie at Yale, his scenarios and sketches gave him a calling card to begin work with a variety of studios - Edison, Vitagraph, Fox, Universal and, by 1920, Metro. He worked on scenarios, acted a bit, and began to receive

ISSN 1699-311X 
opportunities to direct.

His temperament was volatile as evidenced by the short periods at these studios, as he invariably fell out with numerous superiors and co-workers. He came across as a talented but difficult and demanding artist.

Fortunately, at Metro Ingram flourished with equally talented artists, technicians, and producers around him. Barton deftly reveals how actress Alice Terry, scenarist June Mathis, cameraman John Seitz and editor Grant Whytock together kept the tyrannical perfectionist Ingram on track. He followed up the huge success of The Four Horsemen of the Apocalypse with further blockbusters, such as The Prisoner of Zenda (1922) and Scaramouche (1923). All of these films have been remade over the years. Critics were deeply impressed by the pictorial qualities of Ingram's cinema - his choice of locations, his understanding of utilizing depth within the frame, his set decoration, and appreciation for the lit human figure in moving pictures. Stunning images, yes, but comments that would eventually emerge again and again in the critiques of his films were the lack of dramatic pacing and the unrounded characterization.

Barton draws attention to this weakness late in her book by analyzing the two novels and occasional short stories Ingram wrote or published after his film career was over. He was not a gifted writer, but he could compose beautiful shots. Rather like a sculpture, Ingram did not move his rather static aesthetic with the trends of the time. This explains why his career petered out after 1926 and was over as a filmmaker by 1933 when he was forty years old. Like many early cinema artists, he did not take to the "talkies". Only his last picture, Baroud, was a sound film. Other reasons for his fall from favour were self-inflicted ones - he left for France in the mid twenties and set up his own studio in Nice from where he produced his films for MGM. His European aesthetic was critically popular in France but did not play as well in the United States. His obsession with North Africa was overdone by the late 1920s. But it may well have been the case that Ingram, always a restless soul, had simply lost interest in the movies. He did not suffer financially from the Wall Street
Crash, and enjoyed travelling across North Africa. Eventually, in 1933 he converted to Islam, further alienating him from Western culture. His last seventeen years are taken up with constant movement, work as a sculptor and writer, and taking numerous extended vacations. It is hard not to see him as a (soft) Orientalist; as Barton suggests, there was always something Victorian about his values and instincts. He certainly became an avid collector of ancient artifacts, a common Victorian obsession.

Apart from a recent general book by Leonard Gmuer in 2013 on the same subject, which I have not yet had the opportunity to read, Barton's only real critical precursor was Liam O'Leary whose book on Ingram was published initially in 1980. Lavishly illustrated, O'Leary's text is still worth reading today as his overall judgments on Ingram as a romantic artist are perfectly reasonable and not too far from Barton's own considered views. Both Barton and O'Leary, for example, see major critical worth in the lesser-known features Mare Nostrum (1925) and The Magician (1926). Though an avid collector of things related to Irish and early cinema, O'Leary was not a career academic (although he also wrote a useful volume on silent cinema in 1965) and so Barton's work usefully goes over the same ground in a more rigorous and exacting manner, teasing out the man and his work, warts and all. And there are certainly warts to be treated here. We learn from Barton that Ingram had at least four mistresses (all invited by his second wife Alice Terry to his funeral) and that he occasionally frequented prostitutes; however, these dalliances do not seem to have caused too much disruption to his married life, and Barton does not spend much time on them. Theirs was perhaps a modern open marriage since Alice Terry was not averse to having a lover herself. Parenting was not high on Alice Terry or Rex Ingram's agenda - after spontaneously adopting a North African child, he was given some money and sent back when they tired of him. Ingram had an odd tendency to have dwarfs in and around his films that would not pass any political correctness test today. Perhaps of more historical and critical interest are his anti-Semitic views that he seemed to have held fairly consistently throughout his life, 
exacerbated by his disagreements with movie mogul Louis B. Mayer. Ingram would routinely ensure Mayer's name did not appear on his film's credits - only Metro-Goldwyn was allowed. Ingram also seemed to some to hold grudges and was not shy of using the courts to fight for what he considered his property.

Barton's book is magnificently illustrated with seventy-four black and white photos of Ingram's film work, his sketches, and sculptures. She has drawn on apt material from numerous archives the Liam O'Leary Film Archive in the National Library of Ireland (still, sadly, uncatalogued), the Trinity College Dublin archives, The Library of Congress, and private collections. One passing regret, I think, is that the reader would have benefited from a stronger overall sense of his sculptures, and how they relate or not to his film work, since this aspect seems key to his art. The sculptures were sold off years after Ingram's death; they are widely dispersed and in private hands for the most part. A full visual inventory may thus be elusive to analyze.

Barton makes the interesting critical comment that there is something ghostly about Ingram's cinema, and she links it to a gothic sensibility (which, of course, emanates from Irish Protestant figures - Charles Maturin, Bram Stoker et al), a vague kind of desperation or existential dread which might also be linked to the fact that many of his schoolmates in Ireland, including his brother Frank, fought in the hell of the trenches in WW1. Rex's brother had to recover from being gassed, but survived the war and indeed lived until 1972. It would not be unreasonable for Rex to see his generation as a lost one - not just from the war, but from Ireland (both his brother and father left Ireland to settle in England in the 1920s). It would help to explain the restlessness that Ingram exhibited. Barton includes a reproduction of Alice Terry's portrait of Rex Ingram in the last decade of his life. It captures his movie-star looks and strong features, and yet there is a melancholy that pervades the image. Given the constant debate today about Islam and pictorial representations, perhaps it is no accident that Ingram's giving up a film career coincided with his religious conversion. We can only speculate. In the meantime, Barton's assured and elegant work will allow future critics to begin with confidence to interrogate the mystique of this Irish-born and Euro-American filmmaker.

\section{Works Cited}

Leonard Gmuer. 2013. Rex Ingram: Hollywood's Rebel of the Silver Screen. Epubli GmbH.

O'Leary, Liam. 1965. The Silent Cinema. New York: E.P. Dutton.

O'Leary, Liam. 1980. Rex Ingram: Master of the Silent Cinema. Dublin: Academy Press.

Brian McIlroy is Professor of Film Studies at The University of British Columbia, Canada. He is the author, editor or co-editor of six books, including Irish Cinema: An Illustrated History (1988), Shooting to Kill: Filmmaking and the 'Troubles' in Northern Ireland (1998) and Genre and Cinema: Ireland and Transnationalism (2007). One of his current projects is exploring the extant work of Irish-Canadian actor and director Sidney Olcott. 
The Black Irish Onscreen: Representing Black and Mixed Race Identities on Irish Film and Television By Zélie Asava

Oxford, Bern etc.: Peter Lang, 2013

ISBN 978-3-0343-0839-7 (Ebook also available)

Softcover, 203pp.

\section{Reviewer: Maria Pramaggiore}

In this ambitiously conceived book on the intersectionality of black Irish identities, Zélie Asava trains her gaze on the intercultural, the outsider, the migrant, and the diasporic subject, as envisioned within contemporary Irish film and television from the Celtic Tiger into the twenty first century. Asking "how is the relationship between white and black Irish expressed in Irish visual culture?" (2), Asava focuses variously on mixed-race characters, interracial couples, black men in film and "mixed" women on television. The films and television programs examined range from familiar international releases - Neil Jordan's The Crying Game (1992) and John Michael McDonagh's The Guard (2011), for example - to homegrown horror films [Isolation (Billy O'Brien, 2005) and Boy Eats Girl (Stephen Bradley, 2005)], to popular television series (Fair City), to short films Moore Street Masala (David O'Sullivan, 2009), Cactus (Alessandro Molatore 2007), and Milo (Berend and Roel Boormsa, 2012)].

What unites these texts, in Asava's view, are common threads such as "a new focus on the individual and their [sic] relationship to society," emanating from "the excesses of capitalism which led to the label Celtic Tiger Ireland" (5). Moreover, in contemporary Irish visual culture, "the personal is political and a European aesthetic is often privileged over the Americanized style of cinema popularized by Neil Jordan and Jim Sheridan" (6). Despite this statement, Neil Jordan's continuing influence can be inferred from Asava's frequent mention of his films throughout the chapters. Summing up the book's position, the author explains: "Irish screen culture remains quite monolithic and rarely positions the black Irish as part of the collective 'we' of the nation" (21).

The exploration of contemporary films and television programs is shaped by Asava's chosen emphasis on "black/white heterosexual mixed race" (11) characters, a choice based not on a desire to replicate binaries but one necessitated by "the material available and identity politics" (12). This assertion calls for a further elaboration of identity politics as they evolved within Celtic Tiger Ireland in the 1990s and 2000s. The accompanying definition of this concept, which emerged from the 1970s in the US, does not go far enough to historically and theoretically ground the book's analysis of black identities in contemporary Irish popular culture. A discussion of the particular ways in which gender, racial and sexual diversities began to be articulated in political discourses in Ireland during the period in question would be welcome.

With a stated interest in representations of the "new Irish" of the Celtic Tiger era, the author promises a Critical Race/Ethnicity Studies approach to "how screen images correspond with real life histories and how this affects concepts of Irish identity, history and nation" (2). The central position of this sociological perspective, pairing reality with representation, explains the author's frequent movement between fictional texts and social history.

In this regard, one strength of the book is its interest in the relationships among texts, performers, and social practice. Discussions of the social and semiotic significance of actor and performers such as Samantha Mumba and Ruth Negga are scattered across several chapters. If pursued in a more deliberate fashion, the topic 
might have yielded a fruitful analysis of the intersection of star persona and raced identities in the contemporary Irish context. The actors' performances and their cultural resonances which will also inevitably be related to gender, sexuality and race - are shaped by the industry and fan cultures that brand and individuate them, as Richard Dyer's pioneering work (alluded to in the book) addresses. Stardom's emotional cathexis is one important route by which fictional works create a lasting impact on culture. The book's stated interest in the way popular culture texts both reflect and contribute to material and political culture might be more fully articulated through a firmer theoretical foundation in active spectatorship practices.

In general, a clearer statement of the author's view on the relationships between texts and social practice would be helpful for clarifying the larger significance of the individual textual readings, which tend to focus on plot and character. This is especially important given the underlying political motivation for the project: the author writes that it is "crucial to explore these relationships, and their representations on screen, as Ireland moves forward to become an intercultural society and strives to avoid the problems of other European states regarding hate crime and social division" (26). Given this instrumental outlook on the role of film and television, it would be helpful to understand the author's position on the way fictional representations have influenced the economic and cultural shifts of the last two decades in Irish culture and might influence them in future. It is non-controversial to propose that films both reflect and shape cultural attitudes and practices; explicating those mechanisms in specific contexts would have produced a richer analysis.

The book's sociological basis, its implicit quest for positive images (the author notes, for example, that Jordan has never created a "normative interracial or homosexual love story" (59), and its strict focus on characterization inform its textual analyses, which tend not to differentiate between fiction and documentary modes of representation, or between film and television. For example, might there be different types of engagement with "black Irish" characters in serial television, a mode that generates ongoing discussion in the Irish press and social media, as opposed to individual feature-length or short films, the latter of which might be screened primarily at festivals to a smaller audience? Furthermore, the visual analysis rarely moves beyond the general (e.g., chiaroscuro lighting in thrillers) to account for the way film and television make meaning. The mention of a medium close up in Chapter Four (116), jumps out as an anomaly, yet this type of detailed reading is precisely what is required throughout the book in the analysis of visual texts because it provides access to cinema's visual strategies of enunciation, which carry its political implications.

Drawing upon the work of Irish film scholars and cultural historians, including Luke Gibbons and Diane Negra, and critical theorists such as Julia Kristeva and Dominique Quessada, Asava asserts the importance of whiteness to contemporary Irish screen representation. The author addresses Ireland's implication in whiteness, frequently with reference to slavery and African American culture, but stops short of fully developing these linkages in the context of the Celtic Tiger economy and migration specifically. Situating whiteness in Ireland calls forth a variety of potentially contradictory contexts - British colonization and empire, the triangular slave trade, Irish emigration, US neocolonialism, contemporary European migration. A legitimate question to ask is whether the critical axes for defining Irish whiteness, growing from academic writing of the 1980s and 1990s, should be reconsidered in light of the massive immigration, primarily from Europe, that Ireland witnessed during the Celtic Tiger period. If theories and practices related to a globalized African American culture remain important (for example, because they are embraced by characters in these films), do they fully articulate the racial dynamics of contemporary, multicultural Ireland?

Fairly late in the book's introduction the author mentions the traditional understanding of the term "black Irish" as the descendants of the survivors of the wreck of the Spanish Armada in 1588 (23). In an attempt to privilege "the new 
Irish" the author misses an opportunity to historicize contemporary ideologies and practices. A concept of black Irishness existed prior to the twentieth century, prior to the inaugural event that the author points to as a frame for the historical situation of the black Irish - the first deportation of a black man in an independent Ireland in 1925 (18). Additionally, the allusions to Esclave maître - a concept originating with Hegel's master-slave dialectic (which remains unmentioned) that has been rearticulated as a simultaneous construct rather than a sequential dialectic within Dominique Quessada's theory of ontological nonseparateness in an autophagic consumer culture are potentially intriguing, but the concept itself, adapted to the Irish context by Michael Cronin, is far too briefly treated. The stated goal of interrogating and disturbing monolithic notions of Irish identity with assertions of its longstanding diversity might be furthered by examining the historical record and engaging in a fuller explication of fewer theoretical terms.

The book is at its most compelling when discussing moments of contemporary popular culture that confront Irish diversity of various kinds - in the visibility of actors such as Ruth Negga, rappers such as Rejjie Snow, the first black Irish mayor, Rotimi Adebari of Portlaoise, and in the rise of film festivals tied to a national heritage - as emblems of the social shifts of twenty first century Ireland. It is as its weakest when visual culture texts are mapped onto reality in a straightforward way and it suffers from numerous typos and grammatical errors (two egregious examples are the misnaming of Ella Shohat as Ezra and the confusion of inference and implication).

Asava's book, though flawed, represents an important first step in examining diversity in popular culture in post-Celtic Tiger Ireland. Perhaps unwittingly, she reveals a film culture that remains in thrall to the imperatives and racial dynamics of a global market. Asava writes that she chose the texts in the book in part because they possess "an innovative approach to racial representations which challenges dominant Western cinematic tropes" (5) whereas her analyses reveal that, with the exception of the "Masala style filmmaking" of Moore Street Masala, Blaxorcist (Edward King, 2007), New Boy (Steph Green, 2007), and of Cactus and Milo, this is actually not the case. Instead, the Irish moving image culture she documents in relation to depictions of blackness, seems to be entrenched in the politics of exclusion and exoticism.

Maria Pramaggiore is Professor and Head of Media Studies at Maynooth University, Ireland. Her latest book is Making Time in Stanley Kubrick's "Barry Lyndon” (Bloomsbury 2014). She is currently coediting a collection on the voice in documentary with Bella Honess Roe and researching a monograph on the horse in cinema and modern visual culture. 
Masculinity and Irish Popular Culture.

By Tony Tracy and Conn Holohan (eds.)

Basingstoke: Palgrave Macmillan, 2014

\section{Reviewer: Emma Radley}

Masculinity Studies has certainly experienced a dramatic flourishing in Irish Studies in recent years, with a number of monographs and edited collections published in this area since 2010, including Fintan Walsh's Male Trouble: Masculinity and the Performance of Crisis (2010), Brian Singleton's Masculinities and the Contemporary Irish Theatre (2010), Caroline Magennis'Sons of Ulster: Masculinities in the Contemporary Northern Irish Novel (2010), Joseph Valente's The Myth of Manliness in Irish National Culture, 1880-1922(2011), Irish Masculinities: Critical Reflections on Literature and Culture, edited by Magennis and Raymond Mullen (2011), and Debbie Ging's Men and Masculinities in Irish Cinema (2013). Conn Holohan and Tony Tracy's collection, Masculinity and Irish Popular Culture: Tiger's Tales, published in 2014 by Palgrave (a press which has a notable catalogue in the area of masculinity studies, and indeed published a number of the aforementioned texts) places itself firmly within this burgeoning field, stating in its introduction its desire to "offer a provocative [...] overview of the myriad ways in which Irish masculinity has been imagined and reimagined into being within cultural texts" (4). The collection arises from a conference on the subject held in NUI Galway in 2011, and comprises a hefty sixteen essays, on a variety of subjects and across a variety of disciplines, including sports, popular culture, music film, television, fiction and drama. Such a number of essays certainly promise scope, although there are a number of overlaps between the essays that perhaps work against this potential. There are three chapters on music, for example, and two on post-conflict
Northern Ireland - and some of the chapters cover critical and cultural territory already comprehensively interrogated (and not always in particularly new ways).Perhaps the editors could have used this generous canvas to further increase the breadth of the collection - for example, there is little by way of sustained analysis of race and ethnicity, outside of a brief though engaging discussion in Zélie Asava's essay on "othered" masculinity in Celtic Tiger cinema, and only one essay that deals with recessionary configurations of masculinity, Diane Negra's astutely observed closing essay, "Adjusting Men and Abiding Mammies: Gendering the Recession in Ireland". The collection itself is organised along vaguely formal lines, sometimes helped by obvious connections: the three essays on music comprise "Musical Masculinities", there's a section on theatre and fiction, and a section on masculinity on screen (although the sections on queer masculinities, and the odd final section on postTiger masculinity, which consists solely of Negra's essay, seem oddly constituted within the overall logic of the structure). Tracy and Holohan's introduction, however, does a good job of creating structural and thematic connections between the essays, and solidly lays out the importance of interrogating masculinity and its socio-cultural contexts, and the way in which "gendered bodies function to work through social shifts and tensions" (7).

The editors note rightly in their introduction the dominating influence of R.W. Connell's theory of hegemonic masculinity in the field of masculinity studies generally. It's a pity, therefore, that the collection is as a whole 
somewhat uneven in its taking up of alternative critical tools with which to complicate the ideological construction of Irish masculinity. The editors comment specifically on the critical underpinnings of the collection in the introduction, speaking favourably of a move away from a (post)colonial framework of analysis, and praise the contributors for "considering masculinity and its functions in under-explored fields and texts ... and by drawing on the insights into gender and sexuality by disciplines such as queer studies" (4).Of course, this form of critique has a long history in Irish Studies, particularly in the feminist and queer scholarship of Gerardine Meaney, Kathryn Conrad, Elizabeth Butler Cullingford, Joseph Valente, Patricia Coughlan, Moynagh Sullivan (amongst many others), which seeks to problematize and challenge the postcolonial, epistemological and ontological discourses of Irish national culture, identity and gender. However, only a small number of the essays demonstrate a real critical awareness of this field. Of course it's key to avoid discursive reification or canonisation, but given that much of the work here is indeed directly addressing the intersections of masculinity and nation, it seems important to retain a sense of this analytic tradition in order to avoid reductive, simplistic or ideologically charged dichotomies of gender, national identity, and authenticity. Neither is there much by way of reference to alternative, non-nationally focused paradigms within masculinity studies itself - for example, the significant body of work on the masculine body in film and screen studies over the last two decades, including a number of monographs and collections by Kaja Silverman, Richard Dyer, Yvonne Tasker, Linda Williams, Steven Cohan, and Peter Lehman. However, this issue is not specific to the collection per se, but perhaps an element of a growing field that is still finding its (critical) feet.

The best essays in the collection are those that move beyond the notion of hegemony covered so rigorously by Connell, as well as the simplistic "masculinity-in-crisis" model that typifies much of the critical work on contemporary masculinity and instead productively read masculinity in terms of postmodernism, queer theory, affect theory, performance studies and textuality. Annabel Sheehan's reading of Patrick McCabe's 2006 novel, Winterwood, for example, complicates the notion of crisis masculinity in Ireland as a symptom of globalisation and postmodernity, instead considering the male subjects of the novel through the lens of psychic trauma, memory, language, temporality and history. The essay makes a compelling connection between the Lyotardian unpresentable and the uncanny, and reads the 'broken narrative' of the novel as an engagement with the traumatic uncovering of institutional abuse scandals over the last two decades. Miriam Haughton's startling and arresting essay on Louise Lowe's The Boys of Foley Street (2012) likewise offers a complex engagement with masculinity and crisis. Haughton forcefully asserts the ethical and affective dimension of Lowe's radical and confrontational "postdramatic" theatre form in Anu Productions' "Monto Cycle", and argues strongly that such an interventionist approach forces the spectator/ participant to engage with and receive the performances as testimony rather than as symbolic. Haughton's reading of the performance of "troubled masculinity" in The Boys of Foley Street thus resists an easy and "safe" appropriation of the text as national allegory, while maintaining an emphasis on the local. She argues that the play's presentation of the "lived experience of traumatised bodies situated in site-specific locales" (147) shifts the focus from a generalised ideological reflection to the understanding of "oneself as part of a wider community, and implicated within a culture that creates, sustains, and informs, troubled masculinities" (155). Barry Monahan's piece on RTÉ drama Pure Mule (2005-9) is also refreshing in its approach to neoliberal masculinity that avoids defaulting to the position that consumerism and globalisation equals emasculation and inauthenticity. His reading here of Tiger narratives complicates established dichotomies of interpretation. The use of the Western as a framework of analysis is particularly 
persuasive, and brings forth insightful commentary on masculinity, mobility and futurity.

Besides the particularly noteworthy essays mentioned above, there are also solid pieces on post-conflict masculinity (although Emilie Pine's and Sarah Edge's essays cover similar ground, both bring something fresh to the table - Pine's reading of Steve McQueen's Hunger as aesthetic decommissioning, and Edge's interrogation of the commodification of the masculine victim in the "marketing" of the peace process, are particularly insightful), as well as good readings of contemporary urban masculinity (in Asava's and Negra's pieces, particularly, and in Cormac O'Brien's essay on Celtic Tiger theatre). There is an intriguing, though ultimately not fully realised, presentation of an écriture masculine in the fiction of Sean O'Reilly in Fiona McCann's essay, and in the best of the three essays on music, Sean Campbell's focus on diasporic configurations of Irish masculinity in the band Oasis proves a productive angle of analysis.

As a whole, the collection, while it is a useful addition to this growing field of study, perhaps doesn't fully grasp the opportunity to break new ground, and rather capably, though somewhat predictably, follows critical pathways already established, particularly by Singleton and Ging. With some exceptions, particularly in the three chapters discussed above, the collection's approach to masculinity seems a little safe, and on occasion, a little incidental to the analysis (although the focus may always be on men, it doesn't necessarily follow that masculinity is being examined). Nevertheless, Irish masculinity studies is an important field to cultivate, and all of the essays here are extremely welcome within the broader movement to interrogate and complicate modes of masculine subjectivity in Irish cultural ideology.

\section{Works Cited}

Cohan, Steve and Ina Rae Hark. 1993. Screening the Male: Exploring Masculinities in Hollywood Cinema. London: Routledge.

Dyer, Richard. 1982. "Don't Look Now”. Screen 23.3/4: 61-73.

Ging, Debbie. 2013. Men and Masculinities in Irish Cinema. Basingstoke: Palgrave Macmillan.

Lehman, Peter. 2001. Masculinity: Bodies, Movies, Culture. London: Routledge.

Magennis, Caroline. 2010. Sons of Ulster: Masculinities in the Contemporary Northern Irish Novel. Oxford: Peter Lang.

and Raymond Mullen(eds.). 2011. Irish Masculinities: Critical Reflections on Literature and Culture. Irish Academic Press: Dublin.

Silverman, Kaja. 1992. Male Subjectivity at the Margins. London: Routledge.

Singleton, Brian. 2010. Masculinities and the Contemporary Irish Theatre. Basingstoke: Palgrave Macmillan.

Tasker, Yvonne. 1993. Spectacular Bodies: Gender, Genre and the Action Cinema. London: Routledge.

Valente, Joseph. 2011.The Myth of Manliness in Irish National Culture, 1880-1922. Urbana, Illinois: University of Illinois Press.

Walsh, Fintan. 2010. Male Trouble: Masculinity and the Performance of Crisis. Basingstoke: Palgrave Macmillan.

Williams, Linda. 1999. Hard Core: Power, Pleasure and the "Frenzy of the Visible". Berkeley: University of California Press.

Dr Emma Radley is Senior Teaching and Research Fellow at UCD School of English, Drama and Film. She teaches, researches and publishes in the area of Irish cinema and culture, psychoanalysis, and film theory. She is the co-editor, with Claire Bracken, of Viewpoints: Theoretical Perspectives on Irish Visual Texts, published by Cork University Press in 2013. 


\section{“Other People's Diasporas": Negotiating Race in Contemporary Irish and Irish American Culture} by Sinéad Moynihan

Syracuse, NY: Syracuse University Press, 2013. 242 pp. ISBN 978-0-8156-3310-5

Reviewer: Kathleen Vejvoda

This study of literary and cultural representations of race and immigration in contemporary Ireland focuses on encounters between white Irish and black subjects, exploring the uses and limits of cross-racial sympathy in a wide range of works from 1998 through 2008, including fiction by Joseph O'Connor, Roddy Doyle, Sinéad Moriarty, and Emma Donoghue; drama by Ronan Noone and Donal O'Kelly; comedic performances by Des Bishop; and the films The Nephew (Eugene Brady 1998) and In America (Jim Sheridan 2002). Moynihan's central argument is that these texts tend to set African immigration to Ireland against the backdrop of Irish emigration to the United States - a juxtaposition that often reinforces white privilege. A major strength of the study is its attention to the complexity of these racial interactions and the author's expertise in both Irish and American studies.

What impact has the new multiracial, multicultural Ireland had on white Irish and IrishAmerican literature and culture? Sinéad Moynihan poses this question, seeking to fill a gap in studies of race and immigration in Ireland since the Celtic Tiger, which, with the exception of Zélie Asava's The Black Irish Onscreen [reviewed in this volume] are mainly sociological. Examining fiction, plays, television shows, and films that foreground, in particular, "white Irish interaction with black subjects" (8), Moynihan argues that Irish culture has tended to compare the experience of African immigrants to Ireland since the 1990s with narratives of Irish emigration to the United States - both in the context of the Famine and subsequently. She examines the ethics of such juxtapositions, interrogating the claims and uses of "cross-racial sympathy" in a wide variety of literary and cultural texts. She looks at the ways in which many of these texts imply the "historical-duty argument": the claim that because of their history and continued experience of emigration, the Irish should welcome immigrants to Ireland. But in most of her readings, she finds such parallels between white Irish and black subjects to be problematic for failing to recognize fully the privileges of whiteness.

In her introduction, she lays out what is at stake in her project: nothing less than "the status of postcolonialism as the dominant theoretical framework in Irish Studies" (14). Her theoretical approach, she says, "pits favored positions from Irish studies (postcolonialism) and American studies (critical race studies) against one another"(14). Whereas postcolonial critics have sought to retrieve a history of connections and cooperation between the Irish and other colonized peoples, Diane Negra and the contributors to her 2006 collection The Irish in Us argue that Irish and Irish American invocations of a history of oppression serve to cloak their complicity with white privilege. Though she says she sympathizes with both positions, Moynihan clearly and most consistently aligns herself with Negra's approach.

Chapter One focuses on the representation of Famine Irish and nineteenth-century African

ISSN 1699-311X 
diasporic subjects in Joseph O'Connor's historical novels Star of the Sea (2002) and Redemption Falls (2007), examining the ship as a space of transnational exchange. Drawing on historical documents and personages, these novels "revea[1] the complexities of the relationship that existed between the Irish and African Americans" (47), prompting Irish readers to be aware of the plight of contemporary African immigrants. She presents O'Connor as an example of an artist who "favor[s] ... transnational over national identity" and who can do justice to the history of Irish-black encounters $(59,60)$.

Roddy Doyle's short story collection The Deportees (2007), the focus of Chapter Two, is a more slippery matter. These stories "emphasiz[e] the struggles faced by immigrants and non white people in contemporary Ireland - a Polish nanny, a mixed-race student, a Rwandan schoolboy - as well as the reactions of white, Irish-born people to their arrival" (72). Moynihan argues that The Deportees presents the same interpretive problems as Doyle's other fiction in its habitual "tension between irony and sincerity"(82). In "Home to Harlem," Declan, a mixed-race Irish student, goes to New York to see the birthplace of his African-American grandfather, a narrative that complicates the trope of the roots journey. While Declan romanticizes his African American roots, he is subjected to Irish stereotypes during his tense conversation with his female AfricanAmerican thesis advisor. When he meets an American woman, he ends up performing an "essentialized" Irishness. One of the most interesting aspects of Moynihan's study, as in Negra's collection, is this analysis of Irishness as performance.

Two plays - Ronan Noone's The Blowin of Baile Gall (2002) and Donal O'Kelly's The Cambria (2005) - are the focus of Chapter Three. Both works, she argues, address issues of crossracial sympathy and immigration to contemporary Ireland. She is more critical of Noone's play than of any other text she discusses, stopping just short of calling it racist. In contrast, she finds much to admire in The Cambria, which depicts the visit of African-American abolitionist
Frederick Douglass to Ireland in 1845 . Her comparison of Douglass with another freed slave - St. Patrick - is startlingly original. But Moynihan is also wary of the ways in which texts such as The Cambria deploy the historical-duty argument and probes more troubling aspects of the play such as O'Kelly's decision to play Douglass himself, "in whiteface" (130). Moreover, comparing the cross-racial sympathy in O'Kelly's play to studies of white readers' responses to contemporary African-American historical fiction, Moynihan perceptively asks how radical such "retrospective sympathy" can really be (132). She concludes that "[e]ven in the service of building a tradition of Irish antiracism, ... the appeal to cross-racial sympathy is a strategy that poses all sorts of representational problems" (132).

In Chapter Four, Moynihan scrutinizes the persona of popular comedian Des Bishop, "a white Irish American from Queens, New York", which he trumpets as "the most culturally diverse place on the planet"” (134). Because of his childhood in Queens, "Bishop presents himself as possessing the expertise to comment on Ireland's newfound multiculturalism" (147). Among other performances, Moynihan examines his RTÉ reality television show In the Name of the Fada (2008), in which he goes to live for a year in the Connemara Gaeltacht to learn Irish. Again here she elucidates the performative aspects of Irishness - most notably language and accent - foregrounding moments in which non white, non-Irish subjects learn to perform this Irishness, for example when Bishop meets a Korean-American man who has learned Irish from a CD. When Bishop rhapsodizes about feeling a "genetic connection" to the Irish language, she faults him for being unwilling or unable to perform the radical relinquishment of a sense of stable Irishness that would facilitate alternative, non white ways of "being Irish" or of participating in Irish culture (160-61). But if this sense of stable Irishness is always reducible to whiteness and must be relinquished as incongruous with inclusivity, as Moynihan suggests, is there a place for white Irish people's engagement with traditional Irish culture in a 
multicultural Ireland, or does it inevitably bolster white power and privilege?

My main criticism of this study, however admittedly perhaps unfair, since Moynihan is focusing on race - is that her attention to the importance of class and gender is uneven. While the Bishop chapter is absorbing in many ways, one senses a reluctance to draw out the implications of her claims about Bishop's selfconstruction as "a canny critic of Irish racism" (135). Here I am reminded of Debbie Ging's critique in Men and Masculinities in Irish Cinema (2012) of the cultural productions of two other brash sons of Irish immigrants (in this case to London), Martin and John Michael McDonagh. Moynihan's reading of Bishop's persona could benefit from a similar attention to masculinity and a development of her points about class as well as race. While she acknowledges Bishop's privileged upbringing (the mere fact that his parents could move back to Ireland so that he could attend boarding school), and while she concludes (drawing on Elizabeth Butler-Cullingford's phraseology) that "he is more 'unlike' than 'like' recent immigrants to Ireland", it is hard to determine what we should take away from her critique about Bishop's ethical self-positioning. Her arguments throughout about white privilege at times work against her reading of Bishop: for example, her claim that returning Irish emigrants "wield a double moral power" (136) is unconvincing when she applies it to him, though it makes sense in relation to the mixed-race character of Chad Egan-Washington in The Nephew.

In Chapter Five, she incorporates discussions of gender and sexuality in her analysis of race in the films The Nephew and In America. Citing my argument (2007) that these films are "attempts to come to terms with the role of race in Ireland's rather than in America's - future", Moynihan argues instead for "the inextricability of the Irish from the American contexts of the films" (her emphasis). She interprets Chad, the mixed-race returned Irish American in The Nephew, as a "tragic mulatto", an American archetype (170). This chapter is among the strongest, not least because of its compelling argument about the cultural importance of 70s rock star Phil Lynott, who "has become liberal shorthand for the possibilities offered by a multicultural Ireland" (178). She argues that "[i]n The Nephew, Chad comes to embody the same crossings and identities transatlantic, racial, musical - as Lynott" (177). Drawing on Garner and others, she claims that the Thin Lizzy frontman (like Irish-Nigerian footballer Paul McGrath) has been represented in popular culture as an Irish version of the tragic mulatto. She is quick to recognize the problems with this representation and to point out the exceptionalism associated with mixed-race celebrities such as Lynott and McGrath. She quotes Garner's assertion that " " $[t]$ he experiences of not-so-famous black Irish people have been of lifelong rejection and marginalization"' (179).

Given Moynihan's usually thorough attention to Irish media and popular culture in situating her arguments, one surprising omission here is Christine Buckley, who merits at least a reference. Born in the mid-1940s, Buckley (who died in March 2014) was the mixed-race daughter of a married Irish woman and a Nigerian medical student; she was abandoned by her parents and raised by nuns at an industrial school, where she suffered abuse over many years. While she was not a cultural icon like Lynott, she did become a well-known advocate for survivors of clerical abuse, appearing repeatedly in the Irish media throughout the 2000s. Especially when one takes into account the gendering of the tragic mulatto/a, it would be fascinating to consider whether or not Buckley too - who found solidarity with white survivors of clerical abuse, including men such as Michael O'Brien - has been cast according to this archetype.

In the Epilogue ("The Departees?"), Moynihan compares Roddy Doyle's short story (later adapted into a play) "Guess Who's Coming to Dinner" (2000) with Sinéad Moriarty's novel Whose Life Is It Anyway? (2008), critiquing the ways in which both texts ultimately nullify Irish patriarchal fears not only about interracial relationships, but also about guest workers in Ireland. In terms of public policy, Moynihan is critical throughout her study of the 2004 constitutional amendment that, while supporting 
citizenship rights for diasporic subjects, denied automatic citizenship to those born in Ireland. Here she extends this critique to Ireland's workpermit system, arguing that Doyle's story, in which the African immigrant "leaves of his own accord," is "ultimately reassuring for white Irish readers" (196).

Her discussions of Moriarty and of Emma Donoghue's novel Landing (2007) are especially welcome, given that the texts she discusses throughout are mostly by men and about men. In Landing, she examines the politics of race, gender, class, and emigration/immigration, tracing the failure of any kind of sympathy on the part of Donoghue's economically privileged, mixed-race Irish character Síle, the daughter of an Indian mother and an Irish father: "Síle's
Narcissism firms the concerns I have expressed throughout this book regarding the potential of mixed-race subjects to challenge Irish whiteness. Even though Síle is a non white, mixed-race Irish subject, she does not destabilize white Irish norms" (204).Of course, one might take some solace in the fact that we can have a protagonist in an Irish novel who is not only mixed-race but also flawed (like any human being), but Moynihan suggests that this character lacks other dimensions. She closes by imagining Roddy Doyle writing a new short story ("The Departees") in which "both white Irish-born and non-Irish subjects" - and presumably non white Irish subjects?- "leave Ireland to seek employment elsewhere" (209). It's only a matter of time.

\section{Works Cited}

Ging, Debbie. 2013. Men and Masculinities in Irish Cinema. London: Palgrave Macmillan.

Negra, Diane [ed.]. 2006. The Irish in Us: Irishness, Performativity, and Popular Culture. London and Durham: Duke University Press.

Vejvoda, Kathleen. 2007. "The Blood of an Irishwoman: Race and Gender in The Nephew and In America". Irish Studies Review. 15:3. 365-76.

Kathleen Vejvoda is a Professor of English at Bridgewater State University, U.S. Her memoir "The Death Knock" appeared in New England Review (as Kathleen Chaplin) and was selected as a Notable Essay of 2013 in The Best American Essays 2014. She is working on a manuscript about the representation of children and childhood in Irish cinema. 
The Woman Who Married Clark Gable

Lance Pettitt and Beatriz Kopschitz Bastos (eds.)

São Paulo: Humanitas, 2013

ISBN: 978-8577322251

Thaddeus O'Sullivan: The Early Films, 1974-1985. 2 DVD set

Irish Film Institute and St. Mary's University (Twickenham, London), 2014.

Reviewer: Jerry White

Reviewing Lance Pettitt's recent work on Irish filmmaker Thaddeus O'Sullivan poses a genuine quandary. On the one hand, I see it as exemplary scholarship. I mean this not in the usual clap-onthe-back, job-well-done kind of way, but rather quite literally, as in "this is an example of the kind of scholarship we really need more of". On the other hand, I cannot help but quibble with some of the most fundamental choices that Pettitt has made, namely the specific film that he has chosen for the most substantial treatment. In the final analysis the "exemplary" part of the response overwhelms the "wish he had chosen a different film" part, there's no question of that. This is the kind of thing people in Irish Film Studies need a lot more of, and this is certainly the way to do it.

The critical objects I am referring to are a book and a DVD set, both devoted to the Irish filmmaker Thaddeus O'Sullivan. O'Sullivan is probably best-known for his 1990 film December Bride (itself the subject of a book-length study by Pettitt, published in 2001), although he also directed more conventional films such as the Troubles-thriller Nothing Personal (1997) and episodes of the British television series Silent Witness. O'Sullivan is thus a key part of Irish film history, having started making experimental films about Irish people in London, then gravitating towards brooding and visually sumptuous narrative films like December Bride before settling onto the eccentric fringes of the media industry of These Islands. The book I am reviewing here, published in 2013, bears the title The Woman Who Married Clark Gable, edited by
Pettitt and Beatriz Kopschitz Bastos. It includes the screenplay of O'Sullivan's 1985 short film The Woman Who Married Clark Gable, an introduction to that screenplay by O'Sullivan himself, essays by four scholars about the film or about O'Sullivan's film work generally, and a DVD of the film itself. Because the book is published by Brazilian press Humanitas and two of the aforementioned scholars are Brazilian, everything is here in both English and Portuguese; the DVD has subtitles in Portuguese and Spanish. The DVD set I am reviewing is called Thaddeus O'Sullivan: The Early Films, 1974-1985. This is a two-disc set, with five films altogether, none of which have been on DVD before and all of which had previously been somewhere between extremely difficult and impossible to see outside of an archival setting. This set features a booklet with essays by Pettitt and the Irish Film Institute's Sunniva O'Flynn, as well as short notes by Pettitt on each film. It is published by the Irish Film Institute, where O'Flynn is a long-time curator and programmer.

I see this work as exemplary for two reasons. Perhaps the simplest of these is because of the quality of the scholarship on display here. The booklet that comes with Thaddeus O'Sullivan: The Early Films is a fine example of different kinds of expertise being brought to bear on material in a way that will genuinely help an interested (perhaps academic, perhaps nonacademic) viewer make sense of the films. O'Flynn's contribution is titled "En-gauging with the Work", and as befits her experience as an archivist focuses on the physical properties of 
these films, specifically their quality as work made in and distributed on $16 \mathrm{~mm}$. This is key to understanding the original context of the films' production and initial reception, and goes a long way towards helping a reader understand the world of independent filmmaking in the 1970s and 80s. In the shift to digital such considerations are too-often lost, and it is archivists and the special expertise that they develop who are best positioned to bring them back to the centre of discussions around world cinema. Pettitt's writing in the booklet is for the most part clear and precise, and does a good job of connecting these films to his ongoing scholarly work around migrant media in a way that is not too dependent on familiarity with the esoterica of these kinds of debates. For someone looking at these films and not quite knowing what to make of them, these essays and notes will be genuinely helpful. The book The Woman Who Married Clark Gable takes a very different tack, but the quality of the writing is also, for the most part, very high. Pettitt's lead essay is a wide-ranging discussion of O'Sullivan's work overall, and does a very good job of placing him in the group, in Pettitt's words, "who collectively formed a 'new wave' of Irish filmmakers that benefitted from the brief life of the first Irish Film Board (IFB, 1981-1986) that emerged from legislation passed after concerted lobbying in 1980" (48). Roy Foster, one of Ireland's most celebrated historians and a surprisingly knowledgeable cinephile, ${ }^{1}$ contributes an illuminating essay on

1. Writing about The Woman Who Married Clark Gable, Foster at one point (198) invokes Victor Erice's Spirit of the Beehive (1973), a very dense and difficult film from late-Franco-era Spain. I don't agree that this is a relevant example, but I admire the effort to make this not-particularly-well-known work part of the conversation. It put me in mind of Foster's 2006 Dublin Review essay "The Red and the Green", where he mentioned Theo Angelopoulos' The Travelling Players (1975) as a comparison for The Wind that Shakes the Barley. That's another example of a historically and politically rigorous, aesthetically ambitious film being compared to a $\%$. the connections between the film and the Seán O'Faoláin short story it's based on. Thaddeus O'Sullivan's introduction to the complete screenplay of The Woman Who Married Clark Gable is just as illuminating as it mixes recollections of the details of production with meditations on the finer points of the characters' psychology and social positions. Across these two objects there is a tremendous amount of really high-quality historical and critical writing, writing that is pitched in very different registers.

The second reason I see this as exemplary has more to do with the state of Irish Film Studies overall. Like so many studies of small national cinemas, it is a lot easier to read about important parts of the cinema's history than it is to see them. I see this in the other cinemas I write about regularly, namely Canadian cinema and Swiss cinema. At this stage in the game the critical and historical framework is in place; there are solid narrative histories available, along with studies of key filmmakers and close readings of key films. That work, for the most part, is done, but much contemporary scholarship focuses on trying either to re-do it or do work on its margins (and I am as guilty of this tendency as anyone else). What we lack in studies of national cinemas like Canada's, or Switzerland's, or Ireland's, is reliable access to the films themselves, many of which remain out of print or were simply never released on VHS or DVD or streaming video, generally for reasons that nobody can quite explain. To say that the kind of work that Pettitt and Kopschitz are undertaking here (which follows on a similar book, also published with Humanitas in 2011, devoted to John T. Davies' film The Uncle Jack) is necessary would thus be a colossal understatement. The continued unavailability of "canonical" Irish films such as Pat Murphy's

. work that strikes me as just above mediocre, but again, I could not help but admire the grasp of the finer points of film history on display there. 
Maeve and Anne Devlin (neither of which have ever been released on video), Margo Harkin's Hush a Bye Baby (released some years ago on both VHS and DVD but now nearly impossible to find), Cathal Black's Our Boys (never released on video) or Joe Comerford's Reefer and the Model (released on VHS but never on DVD) strikes me as nothing short of scandalous. Until the publication of Thaddeus O'Sullivan: The Early Films, 1974-1985, I'd have added Thaddeus O'Sullivan's A Pint of Plan and On a Paving Stone Mounted to that list. A student working her way through standard histories of Irish cinema such as Ruth Barton's Irish National Cinema or Martin McLoone's Irish Film: The Emergence of a Contemporary Cinema (both more than a decade old now but both still very durable and quite widely used at the undergraduate level) will more often than not be flummoxed as she tries to actually see what the authors are talking about. Scholars like Pettitt, who are taking this matter in hand by working with archivists, filmmakers and international publishers to make key films more widely available, deserve the most vigorous thanks and support that we can muster.

Having said that, there is something about Pettitt's and Kopschitz Bastos's edition of The Woman Who Married Clark Gable that I find a little curious. I saw the film almost twenty years ago, when researching my MA thesis at the Irish Film Archive, and had not seen it since. I had only the faintest memories of it. Upon rewatching it, I must say I did not experience any kind of epiphany. That was not at all the case when I re-watched films like A Pint of Plain (1975), which is part of Thaddeus O'Sullivan: The Early Films, 1974-1985 and which I had actually seen a bit more recently (in addition to that 1997 trip to the archive I had seen it again in 2002 at a UCD film conference called "Keeping it Real", where Pettitt was a keynote). A Pint of Plain is a crazy little masterpiece, rambling and disorganised and rigorous all at once, a pleasure to look at and a marvel to consider. My memories of being excited by it in both 1997 and
2002 came rushing back as I watched it again on the desktop computer in my study. The Woman Who Married Clark Gable is a different story. Roy Foster's essay in the Pettitt / Kopschitz Bastos book opens by describing the O'Faoláin work on which it's based as "a slight and rather unsatisfactory short story" (193), and despite Foster's and Pettitt's best efforts, I cannot help but consider that to be a good description of the O'Sullivan film as well. I can only guess at the reason that this was the film that Pettitt chose for the more full scholarly and archival treatment, although I suspect that it has something to do with the fact that it stars a youngish Bob Hoskins (who had only appeared in a few films in 1985 before being nominated for an Oscar in 1986 for Neil Jordan's Mona Lisa) and Brenda Fricker (who in 1985 was known mostly as a highly professional television actress, before winning an Oscar in 1990 for Jim Sheridan's My Left Foot). Furthermore, among O'Sullivan's short films, this is the one most likely to seem vaguely familiar, having played alongside Letter to Brezhnev on UK cinema screens. Still, I am sceptical that the film - a strikingly black and white story about a defeated but movie-mad working class Irish woman married to a sweet but slightly dense Methodist Englishman - really repays this level of critical engagement. Viewers approaching truly oddball films like A Pint of Plain or 1978's On A Paving Stone Mounted (also on Thaddeus O'Sullivan: The Early Films, 1974-1985) could really do with some critical assistance, and those films illuminated much more about the English-speaking avantgarde than The Woman Who Married Clark Gable does about broad problems in 80s narrative cinema.

That is all to say: this is excellent work, I just wish that some of that work had been focussed in a slightly different direction. All in all, though, that is a minor complaint, and one that comes close to the cardinal sin of reviews like this, which is being prescriptive. Pettitt and Kopschitz Bastos made their choices and the writing that they marshal around those choices is for the most part excellent. On the larger issue, that of the 
desperate need for scholars to take more of a role in making the primary texts of Irish cinema available and understandable, I am quite unambivalent. The work on Thaddeus O'Sullivan led by Lance Pettitt offers a model for other scholars, a model that helps us see what academically serious, publically minded and sustainable film scholarship could look like.

\section{Work Cited}

Barton, Ruth. 2004. Irish National Cinema. New York and London: Routledge.

Foster, Roy. 2006. "The Red and the Green". The Dublin Review. http://thedublinreview.com/the-red-and-the-green/. [accessed 9 February 2015].

McLoone, Martin. 2000. Irish Film: The Emergence of a Contemporary Cinema. London: British Film Institute.

Jerry White is Canada Research Chair in European Studies at Dalhousie University (Halifax, Canada) and the former editor of the Canadian Journal of Irish Studies. His most recent books are Revisioning Europe: The Films of John Berger and Alain Tanner (2011) and Two Bicycles: The Work of Jean-Luc Godard and Anne-Marie Miéville. 